\title{
Effects of sea urchin grazing on seagrass (Thalassodendron ciliatum) beds of a Kenyan lagoon
}

\author{
Teresa Alcoverro*, Simone Mariani \\ Centre d'Estudis Avançats de Blanes (CSIC), Carretera Sta. Bàrbara s/n, 17300 Blanes, Spain
}

\begin{abstract}
We present the results of experimental and descriptive field studies on the effects of dense sea urchin aggregations on seagrass beds in the Mombasa lagoon (Kenya). The study area was dominated by the slow-growing seagrass Thalassodendron ciliatum (49.6\% cover), and supported an average sea urchin density of $1.6 \mathrm{~m}^{-2}$, mostly Tripneustes gratilla $(90 \%)$. In the T. ciliatum meadows, $39 \%$ of the cover was heavily grazed by the sea urchins (more than $75 \%$ dead shoots), $23.4 \%$ was moderately grazed (more than $50 \%$ dead shoots) and $38.5 \%$ was slightly grazed ( $19.8 \%$ dead shoots). We observed 5 aggregations (fronts) of $T$. gratilla in the study area $\left(5000 \mathrm{~m}^{2}\right), 4$ of these within the T. ciliatum meadows. These aggregations were linear in structure, with mean densities of $10.4 \mathrm{~m}^{-2}$, and left in their wake a 'trailing edge' area of defoliated seagrass rhizomes ( $85 \%$ dead shoots). Grazing rates were measured in 2 ways: marked permanent quadrats along the fronts, and sea urchin addition experiments. The first method produced grazing rates of $1.8 \pm 0.43$ shoots $\mathrm{m}^{-2} \mathrm{~d}^{-1}$, and the second produced slightly higher values of $5 \pm 0.86$ shoots $\mathrm{m}^{-2} \mathrm{~d}^{-1}$. New shoot recruitment was estimated from the marked permanent quadrats in the fronts as 0.32 shoots $\mathrm{m}^{-2} \mathrm{~d}^{-1}$. Simple models indicated that the return interval (i.e. the average frequency of the passage of sea urchin fronts through a seagrass patch) for the 'sea urchin grazing fronts' was 99 or $34 \mathrm{mo}$, depending on the method used, and that $T$. ciliatum recovery time was $44 \mathrm{mo}$. We conclude that the sea urchin aggregations observed in the Mombasa lagoon control T. ciliatum density by grazing its exposed apical tips.
\end{abstract}

KEY WORDS: Seagrass - Sea urchins - Herbivory · Grazing · Thalassodendron ciliatum • Tripneustes gratilla

Resale or republication not permitted without written consent of the publisher

\section{INTRODUCTION}

The effects of sea urchin grazing on benthic macrophyte communities have been widely studied. Heavy grazing by sea urchins is important in determining the structure and abundance of both macrophyte and seagrass assemblages in many marine littoral ecosystems. Massive urchin aggregations of the genus Strongylocentrotus have been widely reported to overgraze giant kelp forests (e.g. Bernstein et al. 1981, Hart \& Scheibling 1988, Tegner et al. 1995, Scheibling et al. 1999). Heavy grazing by the sea urchin Paracentrotus lividus can mediate the transition of assemblages from erect algae to coralline barrens in the Mediterranean Sea (Sala et al. 1998).

\footnotetext{
*E-mail: teresa@ceab.csic.es
}

In general, large-scale seagrass overgrazing by sea urchins in temperate seagrass communities does not appear to occur with either the frequency or magnitude reported for kelp forests and algae-dominated communities. Nevertheless, in the tropical western Atlantic, studies have reported sea urchin overgrazing of large meadows of Thalassia testudinum (Camp et al. 1973) and Syringodium filiforme (Maciá \& Lirman 1999, Rose et al. 1999). Whether these patterns of overgrazing represent a general trend along tropical ecosystems outside of the western Atlantic is unknown, as most of the tropical seagrass systems remain still unexplored (see review by Duarte 1999).

Kenyan reefs are ideal sites to study the impact of herbivores on seagrass communities. Seagrass species richness is very high (Wakibya 1995) and the lagoons have a diverse array of sea urchins and fishes as poten- 
tial seagrass herbivores (McClanahan et al. 1994, Mariani \& Alcoverro 1999). In October 1997, while monitoring seagrass meadows in the Mombasa Marine National Park (MNP) lagoon we repeatedly observed the presence of several grazing aggregations of the sea urchin Tripneustes gratilla (localised densities of 137 sea urchins per $10 \mathrm{~m}^{2}$ ) within seagrass beds dominated by the species Thalassodendron ciliatum. The aggregations were in highly defoliated seagrass patches and seemed to be moving through vegetated areas of the meadows as small fronts.

In the light of these observations, we decided to monitor the grazing aggregations in the Mombasa lagoon more closely. We carried out a series of descriptive studies and experiments to: (1) characterise and quantify the principal sea urchin and seagrass species within the Mombasa MNP lagoon, (2) estimate numbers of sea urchin aggregations in the beds, (3) quantify the percentage of dead Thalassodendron ciliatum areas, (4) describe the sea urchin aggregations and evaluate their effects on the $T$. ciliatum beds, (5) quantify experimentally the feeding rates of the sea urchin Tripneustes gratilla within the grazing aggregations and the capacity of $T$. ciliatum to re-grow after being grazed, and finally (6) link small-scale grazing experiments with large-scale meadow dynamics through the return interval for grazing disturbance and the recovery time of the plant.

\section{MATERIALS AND METHODS}

Study site. The study was carried out in the Mombasa MNP lagoon between October 1997 and February 1998. The lagoon is characterised by shallow depths ( 0.3 to $2 \mathrm{~m}$ ) during low tides, is protected from waves and currents, and the seagrass beds are dominated by Thalassodendron ciliatum (Ochieng \& Erftemeijer 1999).

Characterisation of Mombasa lagoon. To characterise the seagrass beds in the lagoon we measured seagrass (all species) abundance (as \% cover), coral and sand abundance (\% cover) and sea urchin (all species) density (ind. $\mathrm{m}^{-2}$ ). Estimates of seagrass, coral and sand $\%$ cover were based on $50 \mathrm{~m}$ line-transects $(\mathrm{n}=10)$ randomly placed over a $\sim 0.5 \mathrm{~km}^{2}$ area within the seagrass beds. Along the transect axis, the position of each transition of sand, coral or seagrass species was recorded as the distance (to the nearest $\mathrm{cm}$ ) to the transect origin. Gaps of $<10 \mathrm{~cm}$ were not considered (see Manzanera \& Romero 2000 for details). Percentage cover of each substrate class (seagrass, coral, and sand) corresponded to their proportion on the line transects.

Sea urchin abundance in the seagrass beds was recorded twice (in October 1997 and February 1998) in
$10 \mathrm{~m}^{2}$ quadrats $(\mathrm{n}=10)$ randomly placed over an area of $\sim 0.5 \mathrm{~km}^{2}$. To obtain the size-distribution of the sea urchins (Tripneustes gratilla), we measured the horizontal diameter of 90 tests (to the nearest $\mathrm{mm}$ ) in October and February.

Sea urchin aggregations in Mombasa lagoon. The sea urchin (Tripneustes gratilla) aggregations were quantified in $50 \times 10 \mathrm{~m}$ belt transects $(\mathrm{n}=10)$ over an area of $\sim 0.5 \mathrm{~km}^{2}$. Additionally, for each sea urchin aggregation observed, we recorded the size of the front in metres (front length and width).

Percentage of dead shoots in Thalassodendron ciliatum meadows. Many dead shoots of $T$. ciliatum (i.e. grazed shoots lacking leaves and apical meristems: Fig. 1) were observed in the Mombasa lagoon. These dead shoots were very irregularly distributed within the meadows, and we found patches with 0 to $100 \%$ dead shoots. The presence of dead shoots was evaluated using a 4-rank visual scale (I: 0 to $25 \%$ dead shoots; II: 25 to $50 \%$; III: 50 to $75 \%$; IV: 75 to $100 \%$ ). Estimates of each rank were based on six 50 $\mathrm{m}$ linear transects within $T$. ciliatum beds. Along the transect axis, the position of each transition of rank (as I to IV) or sand was recorded as the distance (to the nearest $\mathrm{cm}$ ) to the transect origin. Percentage cover of each rank (I to IV) or sand corresponded to their proportion on the line transects. To correct the possible bias of our visual rank estimates, along some of the transects, 3 replicate $50 \times 50 \mathrm{~cm}$

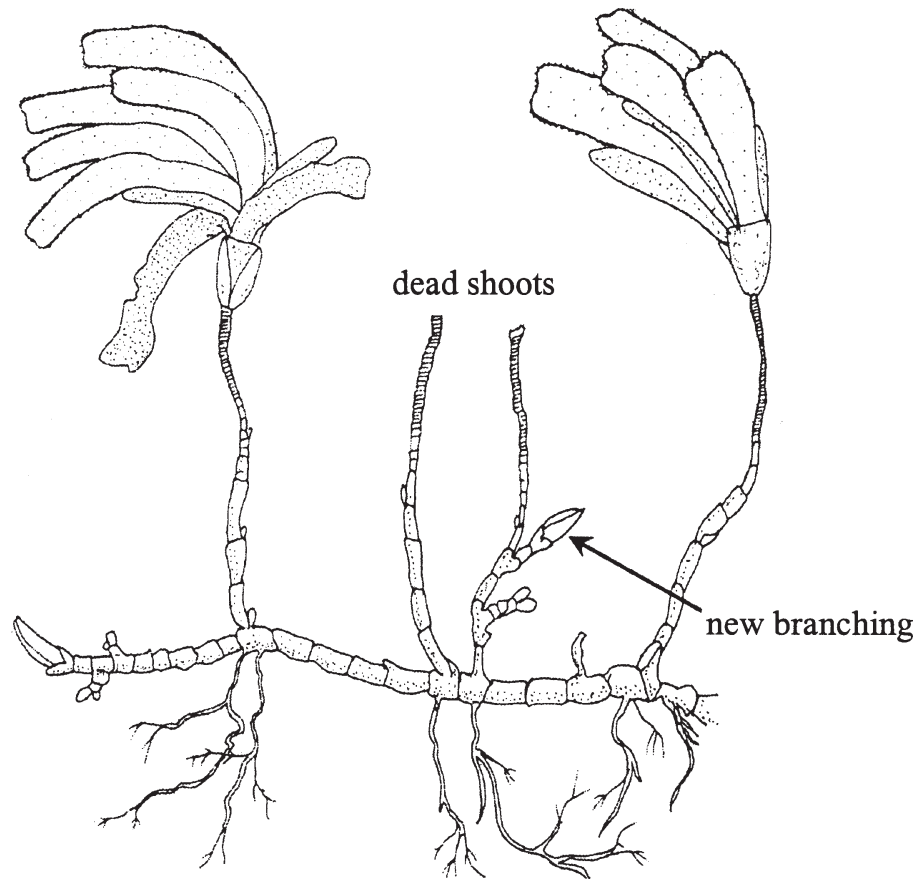

Fig. 1. Thalassodendron ciliatum plant. Dead shoots (lacking leaves and apical meristems), living shoots and new branching rhizomes (new-shoot recruits) are shown 
quadrats were placed in areas visually assigned to each of the 4 visual classes. Living and dead shoots were counted in each quadrat. Average values from this standardisation were used to correct the visual estimates and to obtain the proper proportion of dead shoots.

Characterisation of sea urchin aggregations within Thalassodendron ciliatum meadows. Three randomly chosen sea urchin aggregations, approximately $500 \mathrm{~m}$ apart, were selected, and the impacts of the grazing front were estimated by comparing the $T$. ciliatum dead shoots in front of and behind the urchins. Three belt-transects $(10 \mathrm{~m}$ long $\times 5 \mathrm{~m}$ wide) on an imaginary axis perpendicular to the front were chosen: a 'trailing edge' grazed area, a 'middle' area, and 'leading edge' area (see Rose et al. 1999), which corresponded to seagrass patches with high densities of dead shoots (distance from middle area $=-10 \mathrm{~m}$ ), a high density of sea urchins (distance from middle $=0 \mathrm{~m}$ ) and a moderate density of sea urchins advancing across living seagrass shoots (distance from middle $=+10 \mathrm{~m}$ ), respectively. A fourth area, 'ungrazed by front', (distance from the front $=+20 \mathrm{~m}$ ) was assessed, far enough away as not to be influenced by the aggregations studied. The number of dead shoots in this area was assumed to be the result of factors other than sea urchin front grazing. Within each area, 3 randomly placed quadrats of $10 \mathrm{~m}^{2}$ were sampled to assess sea urchin abundance and 3 quadrats of $50 \times 50 \mathrm{~cm}$ were sampled to assess the number of live and dead $T$. ciliatum shoots ( 3 replicates in 4 areas in 3 'fronts' = 36 quadrats).

Shoot mortality and recruitment rates at the fronts. In the 3 randomly chosen sea urchin aggregations, temporal patterns of grazing were studied to assess grazing and new-shoot recruitment rates in each area of the front. At the start of the experiment, a single permanent quadrat was set up in the trailing, middle and leading edge and the nearby ungrazed areas (four $50 \times$ $50 \mathrm{~cm}$ quadrats in 3 fronts $=12$ quadrats). The number of live and dead shoots was recorded in all the plots. Fifteen randomly chosen dead rhizomes (5 in each front) were marked and monitored to ascertain losses of attached dead rhizomes to sea currents. After $46 \mathrm{~d}$, the number of living and dead shoots in the permanent quadrats and the 15 marked dead rhizomes were counted. New-shoot recruitment, observed as new branching, was calculated as the change in the density of live shoots per quadrat divided by time (46 d), and shoot mortality as the increment of dead shoots per quadrat divided by time (46 d), excluding the loss of attached dead rhizomes.

Experimental additions of sea urchins. To determine the sea urchin grazing rates under controlled experimental conditions, we randomly selected 6 isolated Thalassodendron ciliatum patches of approxi-
Table 1. Summary of total area of Thalassodendron ciliatum plots and number of sea urchins (Tripneustes gratilla) added to each plot during the sea urchin addition (SA) experiment. C: control treatment

\begin{tabular}{|lccc|}
\hline Treatment & $\begin{array}{c}\text { Area } \\
\left(\mathrm{m}^{2}\right)\end{array}$ & $\begin{array}{c}\text { No. of sea } \\
\text { urchins }\end{array}$ & $\begin{array}{c}\text { Sea urchin } \\
\text { density }\end{array}$ \\
\hline SA & 1.5 & 15 & 10 \\
SA & 2.2 & 22 & 10 \\
SA & 1.8 & 17 & 9.4 \\
C & 2.5 & 0 & 0 \\
C & 1.5 & 0 & 0 \\
C & 1.3 & 0 & 0 \\
\hline
\end{tabular}

mately the same size (Table 1) lying apart from the main seagrass beds. These patches were initially sea urchin free, possibly because the surrounding sand acted as a natural barrier to their immigration. We added sea urchins (Tripneustes gratilla) at a density of $10 \mathrm{~m}^{-2}$ (the average density of the middle area of the fronts) to 3 of the patches, while the other 3 were used as control ungrazed plots (Table 1). The initial densities of live and dead seagrass shoots were recorded in the plots. Sea urchins in the 6 plots were checked every 2 to $3 \mathrm{~d}$ and, when required, sea urchins were either added or removed to maintain treatment densities. However, gains or losses in the sea urchin numbers within the experimental plots were near zero. At the end of the experiment (after 47 d) live and dead shoots were counted. The shoot mortality rate was determined as the change in the increase of dead shoots per day.

Thalassodendron ciliatum meadow dynamics. In order to link grazing experiments and meadow recovery, we determined the return interval (i.e. the average frequency of the passage of sea urchin fronts through a seagrass patch) and compared it with the estimated time required for seagrass recovery. In these calculations we assumed that sea urchin densities were constant through time and that shoot recruitment was not density-dependent. During the study period no significant differences in sea urchin density were observed in the study area (see 'Results') and shoot recruitment seemed to be density-independent in the 12 permanent quadrats monitored (see above) as indicated by the lack of correlation between the increase in new shoots (total increase of shoots per plot: live + dead shoots) and the number of live shoots in each plot at time zero $(\mathrm{r}=-0.24, \mathrm{p}>0.05)$.

The return interval for the 'fronts' to a given Thalassodendron ciliatum area $\left(T_{\text {return }}\right)$ was obtained as follows:

$$
T_{\text {return }}=\frac{S_{\text {total }} \times d}{\eta \times S_{\text {front }} \times N_{\text {fronts }}}
$$


where $N_{\text {fronts }}$ is the total number of fronts observed within the $T$. ciliatum meadows, $S_{\text {front }}$ is the average surface $\left(\mathrm{m}^{2}\right)$ of the middle area of the fronts, $d$ is the average shoot density obtained in the ungrazed area (shoots $\mathrm{m}^{-2}$ ), $\eta$ is the sea urchin grazing rate (shoots $\mathrm{m}^{-2} \mathrm{~d}^{-1}$ ), and $S_{\text {total }}$ is the total surface studied covered by $T$. ciliatum $\left(\mathrm{m}^{2}\right)$. This surface was obtained from the total area examined $\left(5000 \mathrm{~m}^{2}\right)$ multiplied by the T. ciliatum percent cover in the lagoon (50\%). The sea urchin grazing rate $(\eta)$ was obtained either from the permanent quadrats or from the sea urchin addition experiment.

The recovery time of a given Thalassodendron ciliatum area ( $\left.T_{\text {recovery }}\right)$ was estimated as:

$$
T_{\text {recovery }}=\frac{d}{\tau}
$$

where $\tau$ is the shoot recruitment rate obtained from the permanent quadrats (shoots $\mathrm{m}^{-2} \mathrm{~d}^{-1}$ ).

Statistics. Statistical significance in sea urchin density and size (test diameter) between periods (October and February) in the Mombasa lagoon was determined by 1 -way ANOVA (Sokal \& Rohlf 1981).

Differences in Tripneustes gratilla (ind. $\mathrm{m}^{-2}$ ) or percentage of dead Thalassodendron ciliatum shoots in the areas of the sea urchin aggregations (trailing edge, middle, leading edge and ungrazed by front) were assessed by a block-design ANOVA with front $(n=3)$ as the blocking factor and area (4 levels) as the treatment factor (Sokal \& Rohlf 1981). The number of dead T. ciliatum shoots at the beginning and end of the experiment was compared with a Student's $t$-test for dependent samples, for the control and the sea urchin addition treatment (Sokal \& Rohlf 1981).

Prior to the analysis, some variables were transformed to normalise the data whenever necessary (i.e. arcsine transformation). In all the statistical analyses, the assumptions of normality (Kolmogorov-Smirnov test) and heteroscedasticity (Leven test) were tested before applying parametric analyses. If significant differences were detected, a posteriori comparisons were conducted using the Tukey HSD test. Differences were considered significant at $\mathrm{p}<0.05$.

\section{RESULTS}

\section{Mombasa lagoon}

A total of 7 seagrass species were observed in the permanently submerged lagoon in the Mombasa MNP (Thalassia hemprichii, Thalassodendron ciliatum, Halophila stipulacea, H. ovalis, Halodule uninervis, Cymodocea rotundata and Syringodium isoetifolium: Fig. 2). Thalassodendron ciliatum was the dominant seagrass species and covered $49.6 \pm 46.5 \%$ of the total
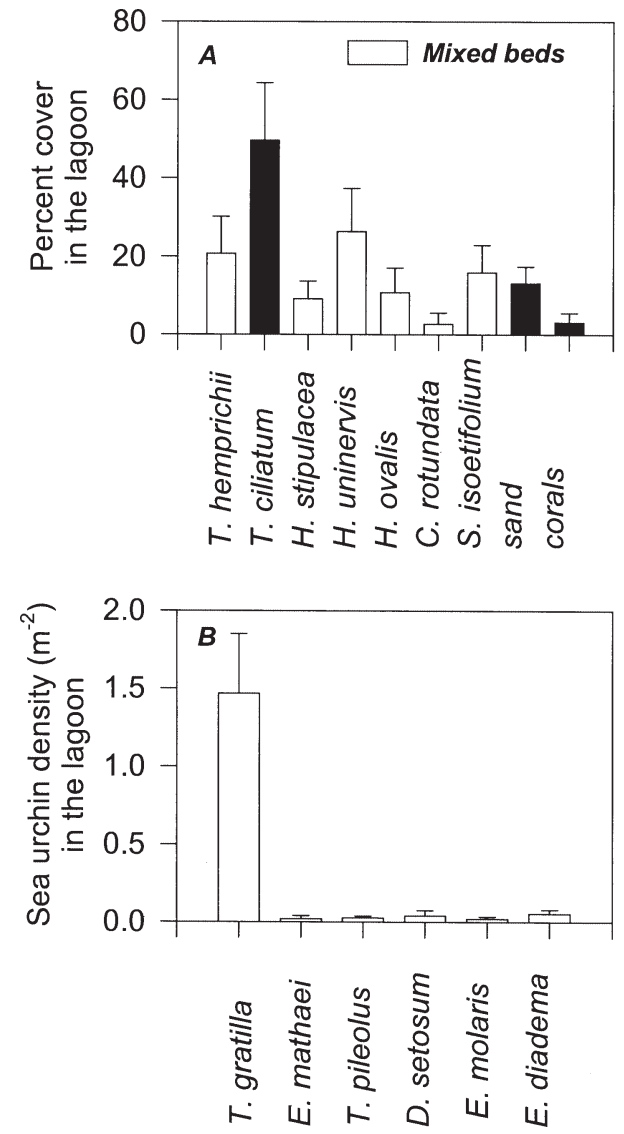

Fig. 2. (A) Percentage cover of coral, sand and the seagrasses Thalassia hemprichii, Thalassodendron ciliatum, Halophila stipulacea, H. ovalis, Halodule uninervis, Cymodocea rotundata and Syringodium isoetifolium obtained from the ten $50 \mathrm{~m}$ transects in Mombasa lagoon; percentage of seagrass, sand and coral cover is higher than $100 \%(152 \%)$ because some of the meadows included more than 1 species. (B) Mean (+SE) density of sea urchins Tripneustes gratilla, Echinometra mathaei, Toxopneustes pileus, Diadema setosum, Echinostrephus molaris and Echinothrix diadema in Mombasa lagoon obtained from 20 quadrats (October 1997 and February 1998)

surface of the lagoon. T. ciliatum formed monospecific beds, while the other seagrasses were always present in mixed beds. Sand and corals covered 13.2 and $3.2 \%$ of the total surface of the lagoon respectively.

A total of 6 sea urchin species was observed in the Mombasa MNP (Fig. 2). Tripneustes gratilla was the most common sea urchin in the seagrass beds, and accounted for $90 \%$ of the total number of sea urchins. The remaining $10 \%$ corresponded to Echinometra mathaei, Toxopneustes pileolus, Diadema setosum, Echinostrephus molaris and Echinothrix diadema. No seasonal variations in sea urchin density (all species) or body size (only T. gratilla) were observed (ANOVA, $\mathrm{p}>0.05$ ). The size of $T$. gratilla ranged from 5.0 to $7.9 \mathrm{~cm}$, with a mean of $6.27 \pm 0.55 \mathrm{~cm}$. Average sea urchin density in the lagoon was $1.6 \pm 0.99 \mathrm{~m}^{-2}$. 


\section{Sea urchin aggregations in Mombasa lagoon}

A total of 5 sea urchin (Tripneustes gratilla) fronts was identified in the study area $\left(5000 \mathrm{~m}^{2}\right)$. Four were in Thalassodendron ciliatum beds and one in a mixed bed dominated by Thalassia hemprichii and Syringodium isoetifolium. The area of these fronts was on average $50 \pm 19.6 \mathrm{~m}^{2}$.

\section{Percentage of dead shoots within Thalassodendron ciliatum meadows}

In Thalassodendron ciliatum meadows, $28 \%$ of the cover showed a high number of dead shoots (Ranks III and IV: Fig. 3), $23 \%$ of the cover was medium-grazed (Rank II: Fig. 3), and $38 \%$ of the cover showed low numbers of dead shoots (Rank I: Fig. 3). The rest of the surface studied was covered by sand (11\%).

\section{Sea urchin aggregation areas}

The number of sea urchins (Tripneustes gratilla) and the percent of dead shoots varied significantly between the areas of the fronts (block-design ANOVA, $F=15.8, \mathrm{p}=0.002$ and $F=19.02, \mathrm{p}=0.01$, respectively; Fig. 4). No differences were observed between fronts (block-design ANOVA, p > 0.05) but the interaction

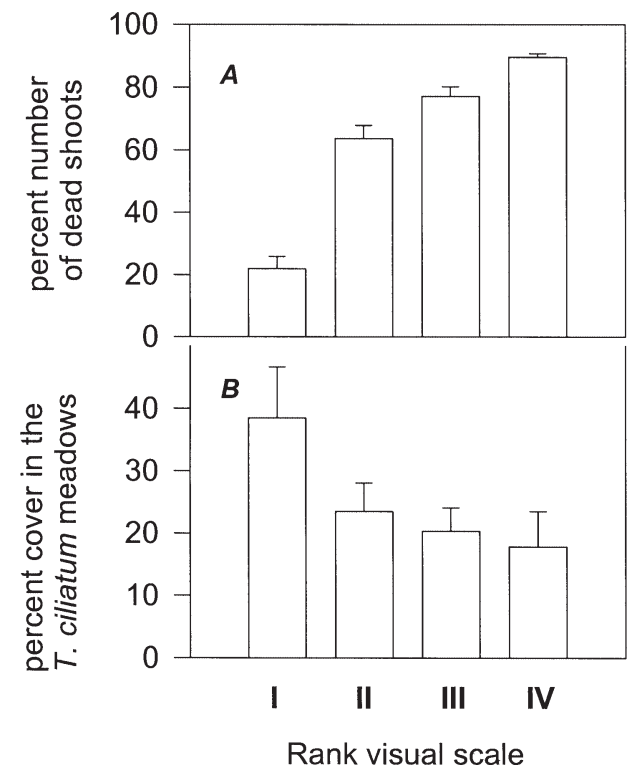

Fig. 3. Thalassodendron ciliatum. (A) Standardisation of rank visual scale (I to IV) to mean (+SE) percent number of dead shoots based on three $50 \times 50 \mathrm{~cm}$ quadrats for each rank; (B) mean $(+\mathrm{SE})$ percent cover of each rank (I to IV) within meadows based on six $50 \mathrm{~m}$ linear transects. Rank I = 0 to $25 \%$, II = 25 to $50 \%$, III $=50$ to $75 \%$, and IV $=75$ to $100 \%$ dead shoots

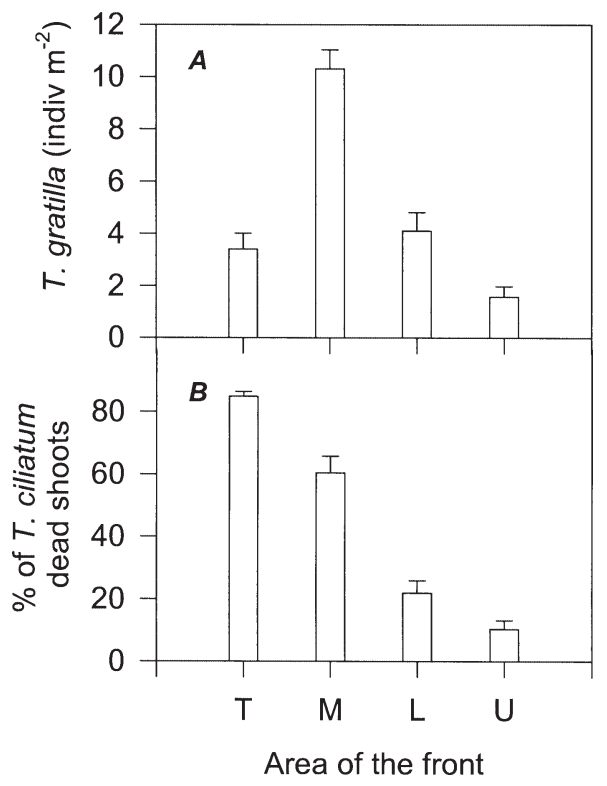

Fig. 4. (A) Mean Tripneustes gratilla density and (B) percentage of Thalassodendron ciliatum dead shoots in the different areas of the 'fronts': trailing edge (T), middle $(\mathrm{M})$, leading edge (L) and ungrazed by fronts area (U). Error bars: SE $(n=3)$

between fronts and area was significant for the 2 variables (block-design ANOVA, $F=3.22$, $p=0.01$, and $F=4.34, \mathrm{p}=0.01$, respectively). All the areas differed in the density of dead shoots (Tukey test, $\mathrm{p}<0.001$ ) except for the areas 'ungrazed by fronts' and 'leading edge' (Tukey test, $p=0.07$ ), indicating that grazers had a significant negative impact on seagrass shoot density. The highest number of dead shoots (85\%) was found in the trailing edge area (Fig. 4). The middle area showed the highest number of sea urchins $(10.3 \pm$ $2.2 \mathrm{~m}^{-2}$, Tukey test, $\mathrm{p}<0.001$ compared with the other areas), with localised densities of 137 per $10 \mathrm{~m}^{2}$ (Fig. 4). The trailing edge, the leading edge and the ungrazed by fronts areas did not differ significantly in their sea urchin densities (Tukey test, $\mathrm{p}>0.05$ ). The 'ungrazed by fronts' area was characterised by a low number of dead shoots $(<10 \%)$.

\section{Shoot mortality and recruitment rates at the fronts}

All 15 marked rhizomes were found after the $46 \mathrm{~d}$ of the experiment, and thus the loss of attached dead shoots to currents was considered to be zero. Shoot mortality was highest in the leading edge area, with approximately 20 dead shoots per quadrat (1.8 \pm 0.43 shoots $\mathrm{m}^{-2} \mathrm{~d}^{-1}$ : Fig. 5). Shoot recruitment rate was highest in the trailing edge area, with an average of $0.32 \pm 0.18$ new shoots $\mathrm{m}^{-2} \mathrm{~d}^{-1}$ (Fig. 5). Shoot recruitment in all the plots was observed as a new branching rhizome. 


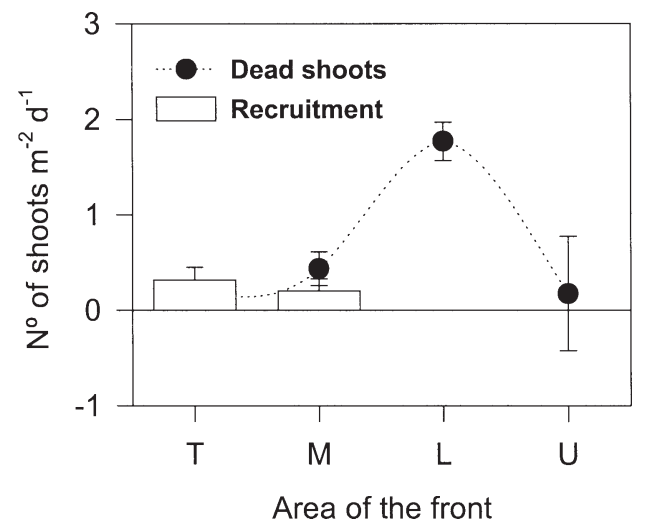

Fig. 5. Thalassodendron ciliatum. Mean grazing (dead shoots $\mathrm{m}^{-2} \mathrm{~d}^{-1}$ ) and new-shoot recruitment rate (living shoots $\mathrm{m}^{-2} \mathrm{~d}^{-1}$ ) in the different areas of the 'fronts': trailing edge $(\mathrm{T})$, middle $(\mathrm{M})$, leading edge (L) and ungrazed by fronts area (U). Error bars: SE $(n=3)$

\section{Experimental additions of sea urchins (Tripneustes gratilla)}

A drastic decrease in shoot density was observed in the sea urchin addition experimental plots (Student's $t$-test for dependent samples, $\mathrm{p}=0.017$ ) compared with controls ( $t$-test for dependent samples, $p>0.05$; Fig. 6 ). After $47 \mathrm{~d}$, the average number of dead shoots $\mathrm{m}^{-2}$ in the treatment plots was $238 \pm 40.7$ shoots $\mathrm{m}^{-2}$, while it was $7.9 \pm 2.24$ in the control, which is very close to the initial record. The grazing rate per sea urchin was estimated at $0.5 \pm 0.08$ seagrass shoots $\mathrm{d}^{-1}$, or $5 \pm$ 0.86 shoots $\mathrm{m}^{-2} \mathrm{~d}^{-1}$, which is higher than that obtained in the permanent quadrats.

\section{Meadow dynamics}

The return interval of sea urchin fronts was estimated using the following variables: the total number of fronts observed $(\mathrm{n}=4)$ within the Thalassodendron ciliatum beds, the total area covered by $T$. ciliatum $\left(S_{\text {total }}=2500 \mathrm{~m}^{2}\right)$, the average area of the sea urchin fronts $\left(S_{\text {front }}=50 \mathrm{~m}^{2}\right)$, the average shoot density in the ungrazed area $\left(811\right.$ shoots $\left.\mathrm{m}^{2}\right)$ and the sea urchin grazing rate (or the shoot mortality rate). Grazing rates obtained from permanent quadrats and from the sea urchin addition experiments gave different return intervals. The first estimation, based on grazing rates in the permanent quadrats $\left(1.8\right.$ shoots $\left.\mathrm{m}^{-2} \mathrm{~d}^{-1}\right)$, gave an average return interval of 187 months $(15 \mathrm{yr})$. The second estimation, which used grazing rates obtained from the sea urchin addition experiment $\left(5\right.$ shoots $\mathrm{m}^{-2}$ $\left.\mathrm{d}^{-1}\right)$, gave an average return interval of $66 \mathrm{mo}(5.4 \mathrm{yr})$.

From the average shoot density in the ungrazed area $\left(811\right.$ shoot $\mathrm{m}^{2}$ ) and the shoot recruitment rate, we esti-

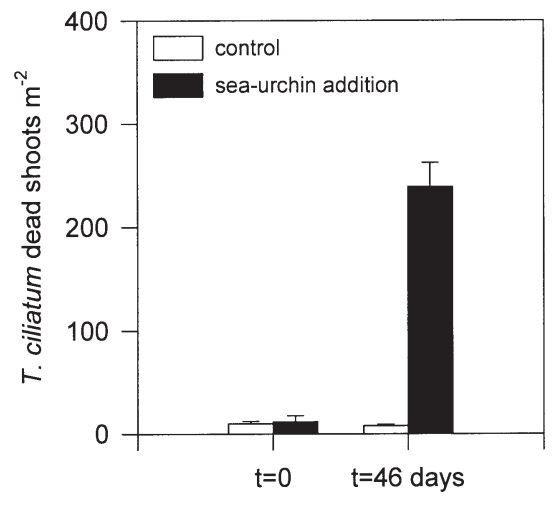

Fig. 6. Thalassodendron ciliatum. Mean $(+\mathrm{SE}, \mathrm{n}=3)$ deadshoot frequency at the start $(\mathrm{t}=0)$ and end $(\mathrm{t}=46 \mathrm{~d})$ of the sea urchin (Tripneustes gratilla) addition experiment in experimental and control plots

mated seagrass recovery time to be $84 \mathrm{mo}(7 \mathrm{yr})$. This regrowth takes place from new branching of completely defoliated shoots.

\section{DISCUSSION}

Tripneustes gratilla dominates the seagrass meadows in the Mombasa lagoon in much the same way that Echinotrix spp. dominate the adjacent coral substrates (McClanahan et al. 1994). The distribution and ecology of T. gratilla has been poorly studied, but several reports have shown the presence or dominance of this species in other seagrass meadows of the Indo-Pacific such as the Philippines, Sinai, Northern Red Sea, Gulf of Aqaba and Papua New Guinea (Hattori 1987, Nojima \& Mukai 1990, Klumpp et al. 1993, Valentine \& Heck 1999). These reports are consistent with the feeding preference of this species for seagrasses (Klumpp et al. 1993). T. gratilla seems to play a similar trophic role to $T$. ventricosus in Western Atlantic seagrass beds, which feeds exclusively on seagrass (Keller 1983, Tertschnig 1989).

The absence of significant differences in sea urchin density or size between sampling periods may indicate a certain stability of the sea urchin population studied. Tripneustes gratilla populations elsewhere have shown considerable seasonal variability in density and size structure (Trinidad-Rao \& Pasamonte 1988). These fluctuations in demography have been attributed to both high recruitment and high mortality rates due to heavy fishing pressure by local villagers (Trinidad-Rao \& Pasamonte 1988, McManus et al. 1991). Nevertheless, recruitment was not observed during the study period in the area monitored, and sea urchins are not fished in the Kenyan seagrass meadows. However, the span of the study was not sufficient to detect long-term 
demographic changes in the sea urchin populations. Such changes are essential to understanding the longterm grazing effect on marine systems (Scheibling et al. 1994). More effort should be made to determine the effects of fluctuations in sea urchin abundance on the seagrass community; only long-term monitoring can determine these dynamics.

The origin of sea urchin aggregations remains unclear, but several hypotheses can be proposed. High densities are the result of both a highly successful recruitment (Hart \& Scheibling 1988, Rose et al. 1999) and the anti-predatory benefits of dense aggregations. In the Mombasa MNP, fish biomass has been observed to be 1 to 2 orders lower than in older Kenyan 'unfished' reefs, but higher than in the unprotected 'fished' reefs (McClanahan et al. 1994). Highly successful recruitment, self-protected aggregations, and moderate densities of predatory fishes may be crucial for the appearance and maintenance of sea urchin aggregations. The aggregations described here may represent a general herbivory pattern, since large aggregations of Tripneustes gratilla have also been observed in other seagrass-dominated ecosystems in the region (Ras Iwatine-Kenya: pers. obs., PraslinSeychelles Islands: E. Ballesteros pers. comm.).

It has been hypothesised that an 'overgrazing' event does not have a long-lasting effect on seagrass-dominated systems, since leaf regrowth occurs rapidly (Valentine \& Heck 1991) or can even increase production during the summer months (Valentine et al. 1997, Rose et al. 1999). Because of the vertical internodes that extend above the sediment, Thalassodendron ciliatum, a slow-growing species (Marbà \& Duarte 1998), has an advantage over possible benthic competitors, which might be shaded by its elevated canopy (Duarte et al. 1996). At the same time, however, this otherwise advantageous morphology has a disadvantage since it allows grazers easy access to the unprotected apicalgrowing tips. Within the sea urchin aggregations, the rhizomes of $T$. ciliatum remain defoliated, with clearly degraded meristems. In this species, the recruitment of new shoots of a plant occurs only as a new-branching rhizome (see Fig. 1), and consequently the capacity of the plant to recover lost biomass depends on the energy stored in the belowground component.

Moreover, the degree of severity of the grazing disturbance in Thalassodendron ciliatum meadows is determined not just by herbivore density, but also by the grazing rate (number of shoots consumed by sea urchins per day). In the study area, the average density of Tripneustes gratilla was moderate compared with that of other species recorded in other parts of the world (e.g. Camp et al. 1973, Maciá \& Lirman 1999, Rose et al. 1999). Severe grazing occurred because sea urchins easily remove the exposed canopy and the apical meristems of $T$. ciliatum. Thus, moderate densities of sea urchins can have a high impact on such meadows. It is also worth commenting that large numbers of partially grazed, detached shoots were observed in the sediment near the experimental plots, indicating that sea urchins can cut the apical tips of the rhizomes and consequently the entire shoot, but that these shoots are not completely consumed. Thus, sea urchin grazing rate is not necessarily related to consumption rate.

Recovery can occur through 2 main processes: seedling recruitment and new rhizome branching. The contribution of Thalassodendron ciliatum seedlings to the recovery of the meadow is presumably low, since our observations did not reveal any recruited seeds and no seedlings have been reported by other authors for the same area (Duarte et al. 1996). In contrast, this study clearly shows that the branching of rhizomes is fundamental to the recovery of grazed areas. Young $T$. ciliatum shoots show amongst the fastest growth of vertical rhizomes recorded for seagrasses (Duarte et al. 1996). This characteristic may be vital for the survival of meadows after persistent grazing.

Although the sea urchin fronts spatially account for a small portion of the Thalassodendron ciliatum meadows, their return interval is likely to be crucial to the recovery potential of the meadows. Our estimates of sea urchin return intervals differed greatly, depending on the grazing rate used in the calculation, based on estimates from 2 independent methods of studying grazing. This raises the issue of the reliability of manipulated field experiments in reflecting reality. On the one hand, the difficulty in obtaining homogeneous quadrats in the mosaic of aggregated sea urchin patches within the 'fronts' may be the cause of the lower grazing rates in the permanent quadrats. On the other hand, addition experiments that confine sea urchins into a limited area may give an overestimate of the real sea urchin grazing rates compared with 'natural' conditions. It is difficult to say what is the best approximation to apply. Different results can be obtained depending on the method used, and this should be taken into account when inferring grazing processes from either experimental manipulations or observations. In the case presented here, the use of one approximation gave vastly different results from the other (i.e. meadow maintenance or its disappearance) and therefore information on long-term demographic changes in the sea urchin populations became of vital importance.

Whether the meadow as a whole is tending to recede or not, urchin grazing rates that are higher than new-shoot recruitment rates will result in the development of a fragmented pattern of seagrass cov- 
erage. Our field observations of dead Thalassodendron ciliatum areas in the Mombasa lagoon highlight the role that sea urchin aggregations may play on the maintenance of this particular seagrass landscape. This is confirmed by the high percentage of dead areas of $T$. ciliatum observed within the lagoon (areas with $>75 \%$ dead shoots). In these areas, the sea urchin fronts were not necessarily present at the time of the survey, indicating the historical effects of sea urchin aggregations on the meadow. For instance, we consider these areas as grazed by sea urchin aggregations because of the patchiness of adjacent barren/unbarren areas, the characteristic landscape observed in areas where sea urchin fronts have grazed. Factors other than urchin grazing (i.e. water turbidity, self-shading, fish grazing) have also been described as causing shoot mortality. However, in such cases we would expect a homogenous decline in shoot density throughout the whole meadow. The effect of such 'other' factors could be observed in the ungrazed by the fronts areas, where dead shoots comprised $<10 \%$ of the total number of shoots.

Previous studies examining the effect of biotic factors (bioturbation) in the seagrass landscape have confirmed bed disruption (e.g. Townsend \& Fonseca 1998). We posit that the presence of high sea urchin densities (sea urchin aggregations) and the consequent disruption or gap formation in a meadow may facilitate the colonisation of seagrass species other than Thalassodendron ciliatum, thereby increasing seagrass diversity. It is worth noting that while some areas of the Kenyan coast that are dominated by mixed seagrass beds show higher sea urchin densities than the Mombasa lagoon, others from which seagrass-eating sea urchins are absent contain continuous meadows of $T$. ciliatum (McClanahan et al. 1994, pers. obs.). Thus, high sea urchin densities may determine the presence of mixed seagrass beds, and the presence of sea urchin aggregations may be crucial to the maintenance of local patterns of the seagrass-bed landscape.

This study of the lagoonal seagrass beds of the Mombasa MNP has shown the profound effect that grazing by the urchin Tripneustes gratilla can have on seagrasses such as the slow-growing Thalassodendron ciliatum, which seems to be more vulnerable to sea urchin grazing than other seagrasses (i.e. Thalassia hemprichii, Cymodocea serrulata, C. rotundata and Syringodium isoetifolium) whose apical meristems are partially protected in the sediment. Although the sea urchin fronts spatially account for a small portion of the T. ciliatum meadow, their high grazing rates can significantly contribute to the decline of this species, and the moderate shoot recruitment capacity of the plant can only partially alleviate this trend.
Acknowledgements. This study was financed by the former Spanish Ministerio de Educación y Ciencia. The Wildlife Conservation Society (Coral Reef Conservation Project) provided hospitality. Kenya's Office of the President and Kenya Wildlife Service provided permission to undertake this research (Research Clearance No. OP/13/001/15C 104, to TA). The valid criticism and comments of Rohan Arthur and 3 anonymous reviewers improved the clarity and the general quality of the manuscript.

\section{LITERATURE CITED}

Bernstein BB, Williams BE, Man KH (1981) The role of behavioral responses to predators in modifying urchins, (Strongylocentrotus droebachiensis) destructive grazing and seasonal foraging patterns. Mar Biol 63:39-49

Camp D, Cobb S, van Breedfield J (1973) Overgrazing of seagrasses by the regular urchin, Lytechinus variegatus. BioScience 23:37-38

Duarte CM (1999) Seagrass ecology at the turn of the millennium: challenges for the new century. Aquat Bot 65:7-20

Duarte CM, Hemminga MA, Marbà N (1996) Growth and population dynamics of Thalassodendron ciliatum in a Kenyan back-reef lagoon. Aquat Bot 55:1-11

Hart MW, Scheibling RE (1988) Heat waves, baby booms, and the destruction of kelp beds by sea urchins. Mar Biol 99: $167-176$

Hattori A (1987) Studies on the dynamics of the biological community in tropical seagrass ecosystems in Papua New Guinea: the second report. Ocean Research Institute, University of Tokyo

Keller BD (1983) Coexistence of sea urchins in seagrass meadows, an experience analysis of competition and predation. Ecology 64:1581-1598

Klumpp D, Salita-Espinosa JT, Fortes MD (1993) Feeding ecology and trophic role of sea urchins in a tropical seagrass community. Aquat Bot 45:205-229

Maciá S, Lirman D (1999) Destruction of Florida Bay seagrasses by a grazing front of sea urchins. Bull Mar Sci 65: 593-601

Manzanera M, Romero J (2000) Multifractal structure in Posidonia oceanica meadows. Biol Mar Medit 7:389-392

Marbà N, Duarte CM (1998) Rhizome elongation and seagrass clonal growth. Mar Ecol Prog Ser 174:269-280

Mariani S, Alcoverro T (1999) A multiple-choice feedingpreference experiment utilising seagrasses with a natural population of herbivorous fishes. Mar Ecol Prog Ser 189: 295-299

McClanahan TR, Nugues M, Mwachireya S (1994) Fish and sea urchin herbivory and competition in Kenyan coral reef lagoons: the role of reef management. J Exp Mar Biol Ecol 184:237-254

McManus LT, Gomez ED, McManus JW, Juinio A (1991) Sea urchin management in Bolinao, Pangasinan, Philippines: attempts on sustainable use of a communal resource. The Second Annual Conference of International Association for the Study of Common Property. University of Manitoba, Winnipeg

Nojima S, Mukai H (1990) Feeding habits of fishes associated with a tropical seagrass bed in Papua New Guinea. Publ Amakusa Mar Biol Lab 10:175-186

Ochieng CA, Erftemeijer PLA (1999) Accumulation of seagrass beach cast along the Kenyan coast: a quantitative assessment. Aquat Bot 65:221-238

Rose CD, Sharp WC, Kenworthy WJ, Hunt WG and 6 others 
(1999) Overgrazing of a large seagrass bed by the sea urchin Lytechinus variegatus in Outer Florida Bay. Mar Ecol Prog Ser 190:211-222

Sala E, Boudouresque CF, Harmelin-Vivien M (1998) Fishing, trophic cascades, and the structure of algal assemblages: evaluation of an old untested paradigm. Oikos 82:425-439

Scheibling RE, Hennigar AW, Balch T (1994) The dynamics of destructive grazing of kelp beds by sea urchins in Nova Scotia. In: Guille BDA, Feral J P, Roux M (eds) Echinoderms through time. AA Balkema, Rotterdam

Scheibling RE, Hennigar AW, Balch T (1999) Destructive grazing, epiphytism, and disease: the dynamics of sea urchin-kelp interactions in Nova Scotia. Can J Fish Aquat Sci 56:2300-2314

Sokal RR, Rohlf FJ (1981) Biometry. The principles and practice of statistics in biological research, 2nd edn. WH Freeman \& Co, New York

Tegner MJ, Dayton PK, Edwards PB, Riser KL (1995) Sea urchin cavitation of giant kelp (Macrocystis pyrifera C. Agardh) holdfasts and its effects on kelp mortality across a large California forest. J Exp Mar Biol Ecol 191:83-99

Tertschnig WP (1989) Diel activity patterns and foraging dynamics of the sea urchin Tripneustes ventricosus in a tropical segrass community and a reef environment (Vir-

Editorial responsibility: Kenneth Heck Jr (Contributing Editor), Dauphin Island, Alabama, USA gin Islands). PSZN I: Mar Ecol 10:3-21

Townsend EC, Fonseca MS (1998) Bioturbation as a potential mechanism influencing spatial heterogeneity of North Carolina seagrass beds. Mar Ecol Prog Ser 169:123-132

Trinidad-Rao M, Pasamonte JN (1988) Growth, mortality and recruitment of the sea urchin Tripneustes gratilla (L.) (Echinodermata: Echinoidea) in Bolinao, Pangasinan, through electronic length-frequency analysis. Annual Project Report Marine Science Institute, University of Phillipines, Quezon City

Valentine J, Heck KL Jr (1991) The role of sea urchin grazing in regulating subtropical seagrass meadows: evidence from field manipulations in the northern Gulf of Mexico. J Exp Mar Ecol Biol 154:215-230

Valentine JF, Heck KL Jr (1999) Seagrass herbivory: evidence for the continued grazing of marine grasses. Mar Ecol Prog Ser 176:291-302

Valentine J, Heck KL Jr, Busby J, Webb D (1997) Experimental evidence that herbivory increases shoot density and productivity in a subtropical turtlegrass (Thalassia testudinum) meadow. Oecologia (Berl) 112:193-200

Wakibya JG (1995) The potential human-induced impacts on the Kenya seagrasses. UNESCO Rep Man Sci 66: $176-187$

Submitted: June 20, 2000; Accepted: April 16, 2001 Proofs received from author(s): January 21, 2002 